Original Research Paper

\title{
Heavy Metals Content of the Grassland Soil around Katima Mulilo Municipal Solid Wastes Dumpsite, Namibia
}

\author{
${ }^{1}$ J. Abah, ${ }^{1}$ P. Mashebe and ${ }^{2}$ S.A. Onjefu \\ ${ }^{I}$ Department of Mathematics, Science and Sport Education, Faculty of Education, \\ University of Namibia, Katima Mulilo Campus, Private Bag, 1096, Katima Mulilo Namibia \\ ${ }^{2}$ Department of Natural and Applied Sciences, \\ Namibia University of Science and Technology, Private Bag, 13388, Windhoek, Namibia
}

\author{
Article history \\ Received: 26-10-2016 \\ Revised: 28-01-2017 \\ Accepted: 16-03-2017 \\ Corresponding Author: \\ J. Abah \\ Department of Mathematics, \\ Science and Sport Education, \\ Faculty of Education, \\ University of Namibia, Katima \\ Mulilo Campus, Private Bag, \\ 1096, Katima Mulilo Namibia \\ Email: jabah@unam.na
}

\begin{abstract}
The effects of open wastes dumpsites on the immediate vicinity continue to generate safety concern. This study determined the levels of lead, chromium, cadmium, arsenic, nickel, cobalt, copper and manganese in soil samples collected at two depths: 0-15 and 15-30 cm within and around Katima Mulilo municipal solid wastes dumpsite and a control site. The samples were digested according to EPA method $3050 \mathrm{~B}$ and analyzed using Inductively Coupled Plasma-Optical Emission Spectrophotometer (ICP: Perkin Elmer Optima 7000 DV). The results obtained revealed that manganese recorded the highest mean concentrations varying between $21.95-91.10$ and $15.12-122.30 \mathrm{mg} \mathrm{kg}$ within the $0-15$ and $15-30 \mathrm{~cm}$ soil depths respectively while Cd (BDL$0.51 \mathrm{mg} \mathrm{kg}^{-1}$ and BDL- $0.86 \mathrm{mg} \mathrm{kg}^{-1}$ ) recorded the least. The analysis of variance between the mean levels of the heavy metals was statistically significant $(p<0.05)$. Assessment of the sampling sites contamination revealed that the Wastes dumpsite $>$ Grassland A $>$ Grassland B > Control site but the current ecological risk indices (0.004-0.824) revealed environmental low risk levels $(\mathrm{Er}<40)$. The correlation coefficients of the heavy metals revealed mainly extremely positive correlations ( $r>$ 0.9). These suggest common source of anthropogenic inputs of the heavy meals. Generally, the mean concentrations of the heavy metals were lower than their corresponding maximum permissible limits recommended by WHO for the protection of human and ecosystem's health. However, the presence of heavy metals in the human ecosystem is regarded as a potential toxin because metals are persistence, non-degradable and bio-accumulative in nature. Therefore, we recommend periodic monitoring of the heavy metals in the soils and advice precautionary measures to limit excessive human exposures to the metal contents.
\end{abstract}

Keywords: Grassland, Heavy Metal Levels, Soil Pollution, Wastes Dumpsite

\section{Introduction}

Solid waste disposal (open dumps, landfills, sanitary landfills or incinerators) represent a significant source of metals released into the environment (Waheed et al., 2010; Iwegbue et al., 2010; Bretzel and Calderisi, 2011; Rizo et al., 2012). In many developing countries, little or no attention is paid to the environmental pollution that may arise from municipal solid wastes disposal at dumpsites. In most instances, the dumpsites are designated open land spaces specifically set aside for the purpose of solid wastes disposal. Depending on a city's level of waste management system, municipal wastes may be dumped in an uncontrolled manner, segregated for recycling purposes, or simply burnt (Abah et al., 2015). The main activities at most urban wastes dumpsites include solid wastes deposition and incineration and these could emit high levels of heavy metals into the atmosphere which are subsequently deposited on to the surrounding soils and vegetations. 
Soil contamination by heavy metals emitted from waste disposal sites is a serious problem in industrial and urban areas (Mandal and Sengupta, 2006). The concentrations of heavy metals in soils around waste dumps are influenced by the types of wastes, topography, run-off and level of scavenging (Ideriah et al., 2010). Due to the disturbances and acceleration of nature's slowly occurring geochemical cycle of metals by man, most soils of rural and urban environments may accumulate one or more heavy metals above defined background values high enough to cause risks to human health, plants, animals, ecosystems, or other media (D'Amore et al., 2008). It is projected that the anthropogenic emission of several heavy metals into the atmosphere is one-to-three orders of magnitude higher than natural fluxes (Sposito and Page, 1984) and these are subsequently deposited on to soils and vegetations. Heavy metals contamination of soil may pose risks and hazards to humans and the ecosystem through: Direct ingestion or contact with contaminated soil, the food chain (soil-plant-human or soil-plantanimal-human), drinking of contaminated ground water, reduction in food quality (safety and marketability), reduction in land usability for agricultural production causing food insecurity and land tenure problems (McLaughlin et al., 2000a; 2000b; Ling et al., 2007).

Environmental pollution data tend to vary extensively and to be subjected to various types of uncertainties due to several factors such as distance from pollution sources and pathways, natural background variation and pollution build-up or accumulation over time (Rashad and Shalaby, 2007). Once present in an environment, heavy metals are non-degradable, putting human beings and animals traversing the place at risks of acute or chronic exposure via inhalation, direct dermal contact and food chain absorption. The World Health Organization (WHO) estimated that about a quarter of the diseases facing mankind today occur due to prolonged exposure to environmental pollution (Abah et al., 2015). The International Occupational Safety and Health Information Centre (IOSHIC)'s report indicated that long-term exposure to heavy metals may result in slowly progressing physical, muscular and neurological degenerative processes that mimic Alzheimer's disease, Parkinson's disease, muscular dystrophy and multiple sclerosis (IOSHIC, 1999). The report also indicated that allergies are not uncommon and repeated long-term contact with some metals or their compounds may even cause cancer (IOSHIC, 1999). It was also noted that most human load of toxic metals is acquired from the ambient concentrations of these metals through inhalation of dust and fumes, ingestion of food and drink and/or absorption through skin in extreme cases (OSHA, 1991; ATSDR, 2003).
Due to trans-boundary effect, it is envisaged that heavy metal pollutants emitted from the Katima Mulilo urban dumpsite could be deposited in the surrounding grasslands and accumulate in vegetations which grow on the soils. The high grazing activities of cattle in the grasslands may expose the animal to certain levels of heavy metal pollutants and therefore, has implication for transfer into human food chain. Moreover, there is no research work done to establish the pollution status of the soils of grasslands around the wastes dumpsite. Thus, this research is a baseline study with the main objective of determining the present levels of environmentally concerned heavy metals in the soils of grassland within the vicinity of the Katima Mulilo solid wastes dumpsite and compares the values with health regulatory guidelines limits. These baseline data will form important reference information for future monitoring of the impact of the wastes dumpsite on the heavy metals content of the surrounding grasslands.

\section{Materials and Methods}

\section{Study Area}

The study location is the grasslands around Katima Mulilo urban wastes dumpsite, located on latitude $17^{\circ} 50^{\prime} \mathrm{S}$ and longitude $24^{\circ} 25^{\prime} \mathrm{E}$ based on the Global Positioning System (GPS) geographical information recorded at the site on 28 May 2015 (Abah et al., 2015). The dumpsite has an estimated longest land dimension of $346.78 \mathrm{~m}$ and widest land dimension, $296.64 \mathrm{~m}$ (Abah et al., 2015). Solid wastes disposal at the site is based on open dumping and incineration and these practices have the potential to release toxic metal elements into the environment (Abah et al., 2015). Thus, the surrounding soils are very prone to trans-boundary pollution owing to emission of several chemical particulates into the atmosphere following wastes incineration at the dumpsite and subsequent deposition on to the surrounding grasslands (Abah et al., 2015). Because of the possible shift of toxic heavy metals via soil-plant-animal-human transfer chain (Wuana and Okieimen, 2011), soils within the vicinity of the wastes dumpsite may become a vehicle for human food chain contamination with heavy metals.

\section{Sample Collection}

The soil samples were collected on 8 different days with each sampling day occurring every fortnight between June-September, 2015. The samples were collected at two soil depths: Topsoil $(0-15 \mathrm{~cm})$ and subsoil $(15-30 \mathrm{~cm})$. On each sampling day, 4 soil samples (for each soil depth) were randomly collected at four different points (approximately $20 \mathrm{~m}$ apart) within the grassland, wastes dumpsite and control site respectively. The chosen control site was a remote 
environment located $17 \mathrm{~km}$ west of the wastes dumpsite. All samples were collected during the still morning weather (between 6:00-8:00) and packed in pre-labelled polyethene bags (Abah et al., 2015).

\section{Sample Pre-Treatment}

The total samples collected on each sampling day were pooled together according to soil depth and mixed thoroughly to ensure homogeneity. Then, one representative sample was taken and filtered through $<2$ $\mathrm{mm}$ stainless steel sieve. Thus, for the 8 sampling days, 8 sub-samples were taken and conveyed to Analytical Laboratory Services, Windhoek Namibia for further processing and analyses for the levels of heavy metals. All materials used for holding samples, homogenization and sieving were pre-cleaned to minimize the potential of cross contamination.

\section{Soil Samples Digestion and Analysis}

The samples were digested according to the reported EPA method 3050 B for Inductively Coupled PlasmaOptical Emission Spectrophotometer (ICP-OES) analysis (Abah et al., 2014). A known amount (1.00 g) of each sieved soil was transferred into a digestion vessel and 10 $\mathrm{mL}$ of $1: 1$ nitric acid $\left(\mathrm{HNO}_{3}\right)$ was added, mixed thoroughly and covered with a watch glass (EPA, 1996). Then, the samples were heated to $90^{\circ} \mathrm{C}$ and refluxed at this temperature for $10 \mathrm{~min}$ after which they were allowed to cool for $5 \mathrm{~min}$ under room temperature. Thereafter, $5 \mathrm{~mL}$ of concentrated $\mathrm{HNO}_{3}$ was added to each, covered and refluxed again at $90^{\circ} \mathrm{C}$ for $30 \mathrm{~min}$ (EPA, 1996). Then, the solutions were allowed to evaporate without boiling to approximately $5 \mathrm{~mL}$ each and cooled again for $5 \mathrm{~min}$. This was followed by the addition of $2 \mathrm{~mL}$ of deionised water plus $3 \mathrm{~mL}$ of $30 \%$ hydrogen peroxide $\left(\mathrm{H}_{2} \mathrm{O}_{2}\right)$ to each. The vessels were covered with watch glasses and heated just enough to warm the solutions for the peroxide reaction to start (EPA, 1996). This was continued until effervescence subsided and the solutions were cooled. The acidperoxide digestates were covered with watch glasses and heated until the volume reduced to approximately $5 \mathrm{~mL}$ again. Then, $10 \mathrm{~mL}$ of concentrated hydrochloric acid $(\mathrm{HCl})$ was added to each, covered and heated on a heating mantle, then refluxed at $90^{\circ} \mathrm{C}$ for $15 \mathrm{~min}$. After cooling, each digestate was filtered through Whatman No. 41 filter paper into a $100 \mathrm{~mL}$ volumetric flask and the volume made up to the mark with deionised water (EPA, 1996).

Ten (10) $\mathrm{mL}$ of each digestate was taken and mixed with equal volume of matrix modifier (EPA, 1996). Then, they were analyzed using ICP-OES (ICP: Perkin Elmer Optima 7000 DV) for the levels of lead, cadmium, chromium, arsenic, nickel, copper, cobalt and manganese.

\section{Data Analysis}

Descriptive statistics was used to compute the mean of the data obtained from eight replicate analyses of the samples. Furthermore, inter-elemental correlation analysis was performed to determine the degree of association between the heavy metals in the soil samples from the three sites: Point source, grasslands and control soil.

\section{Assessment of Site Contamination}

First, the heavy metal concentrations recorded in the soil samples were compared with their regulatory guideline limits based on which informed decision about the site's quality was made. Further assessment of the site's contamination was done using a Contamination factor (Cf), a single element pollution index calculated in order to determine the individual contribution of the heavy metals to the site's pollution, degree of contamination $\left(\mathrm{C}_{\mathrm{d}}\right)$, aimed at providing a measure of the degree of overall contamination in surface layers at a particular sampling site (Rahman et al., 2012), ecological risk factor [Er] (Hakanson, 1980), used here to provide an indicator of each element's ecological risk index and potential ecological risk factor [PEri], which gives insight into the heavy metals toxicity and environment response (Hakanson, 1980). The potential ecological risk factor does not only considers heavy metal level in the soil, but also associate ecological and environmental effects with toxicology and evaluates pollution using comparable and equivalent property index grading method (Qui, 2010). Each of these assessment criteria was calculated using the following equations:

$$
\begin{aligned}
& C f=\frac{\text { Soil metal concentration }}{\text { soil permissible limit of the metal }} \\
& C_{d}=\sum_{i=1}^{N} C F i \\
& E r=T i \cdot C f \\
& P E r i=\sum E r
\end{aligned}
$$

\section{Results and Discussion}

\section{Soil Concentrations of the Heavy Metals in the Study Area}

The results (Fig. 1) present the mean concentrations of lead $(\mathrm{Pb})$, chromium $(\mathrm{Cr})$, Cadmium $(\mathrm{Cd})$, arsenic (As), nickel (Ni), cobalt (Co), copper (Cu) and manganese $(\mathrm{Mn})$ determined in the soil samples collected at the study area. The results showed that at the point source (within the municipal solid wastes dumpsite), Mn recorded the highest mean concentration 
of $88.99 \mathrm{mg} \mathrm{kg}^{-1}$ within the $0-15 \mathrm{~cm}$ upper soil depth and $122.30 \mathrm{mg} \mathrm{kg}^{-1}$ within the subsoil depth (15-30 $\mathrm{cm})$. Cd recorded the lowest mean concentration of 0.51 and $0.86 \mathrm{mg} \mathrm{kg}^{-1}$ with the $0-15$ and $15-30 \mathrm{~cm}$ soil depths respectively. Within the same soil depths, the other results showed that $\mathrm{Cr}$ recorded 12.36 and 9.85 $\mathrm{mg} \mathrm{kg}$, $\mathrm{Cu}$ recorded 12.36 and $4.18 \mathrm{mg} \mathrm{kg}^{-1}, \mathrm{Ni}$ recorded $6.46 \mathrm{~kg} \mathrm{mg}^{-1}$ and $5.51 \mathrm{mg} \mathrm{kg}^{-1}$, while $\mathrm{As}, \mathrm{Pb}$ and Co recorded $5.28 \mathrm{mg} \mathrm{kg}^{-1}$ and $5.81,1.61,3.78$, 1.71 and $2.09 \mathrm{mg} \mathrm{kg}^{-1}$ respectively.

At the northern end of the grassland (labelled as grassland $\mathrm{A}$ ), $\mathrm{Mn}$ also recorded the highest mean concentration of $91.10 \mathrm{mg} \mathrm{kg}^{-1}$ within the $0-15 \mathrm{~cm}$ upper soil depth and $22.12 \mathrm{mg} \mathrm{kg}^{-1}$ within the subsoil depth $(15-30 \mathrm{~cm})$. Cadmium also recorded the lowest mean concentration $\left(0.51 \mathrm{mg} \mathrm{kg}^{-1}\right)$ within the $0-15 \mathrm{~cm}$ soil depth but it was not detected in the subsoil level $(15-30 \mathrm{~cm})$. Within the same soil depths, the other results showed that $\mathrm{Cr}$ recorded 8.50 and $6.27 \mathrm{mg}$ $\mathrm{kg}^{-1}, \mathrm{Cu}$ recorded 2.05 and $4.31 \mathrm{mg} \mathrm{kg}^{-1}$, Ni recorded 4.65 and $3.82 \mathrm{mg} \mathrm{kg}^{-1}$, while $\mathrm{As}, \mathrm{Pb}$ and $\mathrm{Co}$ recorded $5.332 .82,1.48$ and $0.62 \mathrm{mg} \mathrm{kg}^{-1}, 1.83$ and $0.58 \mathrm{mg}$ $\mathrm{kg}^{-1}$ respectively.
The results of the heavy metals obtained at the southern end of the grassland (labelled as grassland B) also showed similar trend with Mn recording the highest mean concentration of 71.37 and $15.12 \mathrm{mg} \mathrm{kg}^{-1}$ within the $0-15$ and $15-30 \mathrm{~cm}$ soil depths respectively. Cadmium was not detected at this sampling point while the mean concentrations of $\mathrm{Cr}$ showed 8.82 and $5.35 \mathrm{mg}$ $\mathrm{kg}^{-1}, \mathrm{Cu}$ recorded 3.80 and $1.31 \mathrm{mg} \mathrm{kg}{ }^{-1}$, Ni recorded 5.29 and $3.38 \mathrm{mg} \mathrm{kg}^{-1}$, As recorded 2.75 and $1.97 \mathrm{mg}$ $\mathrm{kg}^{-1}, \mathrm{~Pb}$ recorded 0.61 and $0.43 \mathrm{mg} \mathrm{kg}^{-1}$ and $\mathrm{Co}$ recorded 0.60 and $0.30 \mathrm{mg} \mathrm{kg}^{-1}$ within the $0-15$ and $15-$ $30 \mathrm{~cm}$ soil depths respectively. At the control site, $\mathrm{Mn}$ still recorded the highest mean concentration of 21.95 $\mathrm{mg} \mathrm{kg}{ }^{-1}$ within the $0-15 \mathrm{~cm}$ upper soil level and 26.63 $\mathrm{mg} \mathrm{kg}^{-1}$ within the subsoil level $(15-30 \mathrm{~cm})$ while $\mathrm{Cd}$ recorded the lowest mean concentration of $0.22 \mathrm{mg} \mathrm{kg}^{-1}$ within the upper soil depth but Co $\left(0.54 \mathrm{mg} \mathrm{kg}^{-1}\right)$ recorded the lowest mean concentration within the subsoil level $(15-30 \mathrm{~cm})$. Within the two soil depths $(0-$ 15 and $15-30 \mathrm{~cm})$, the other results showed mean levels of 5.11 and $8.49 \mathrm{mg} \mathrm{kg}^{-1} \mathrm{Cr}, 3.54$ and $4.33 \mathrm{mg} \mathrm{kg}^{-1} \mathrm{Ni}$, 1.60 and $2.47 \mathrm{mg} \mathrm{kg}^{-1} \mathrm{As}, 0.60$ and $1.61 \mathrm{mg} \mathrm{kg}^{-1} \mathrm{~Pb}$, as well as 0.30 and $0.99 \mathrm{mg} \mathrm{kg}^{-1} \mathrm{Cu}$ respectively.

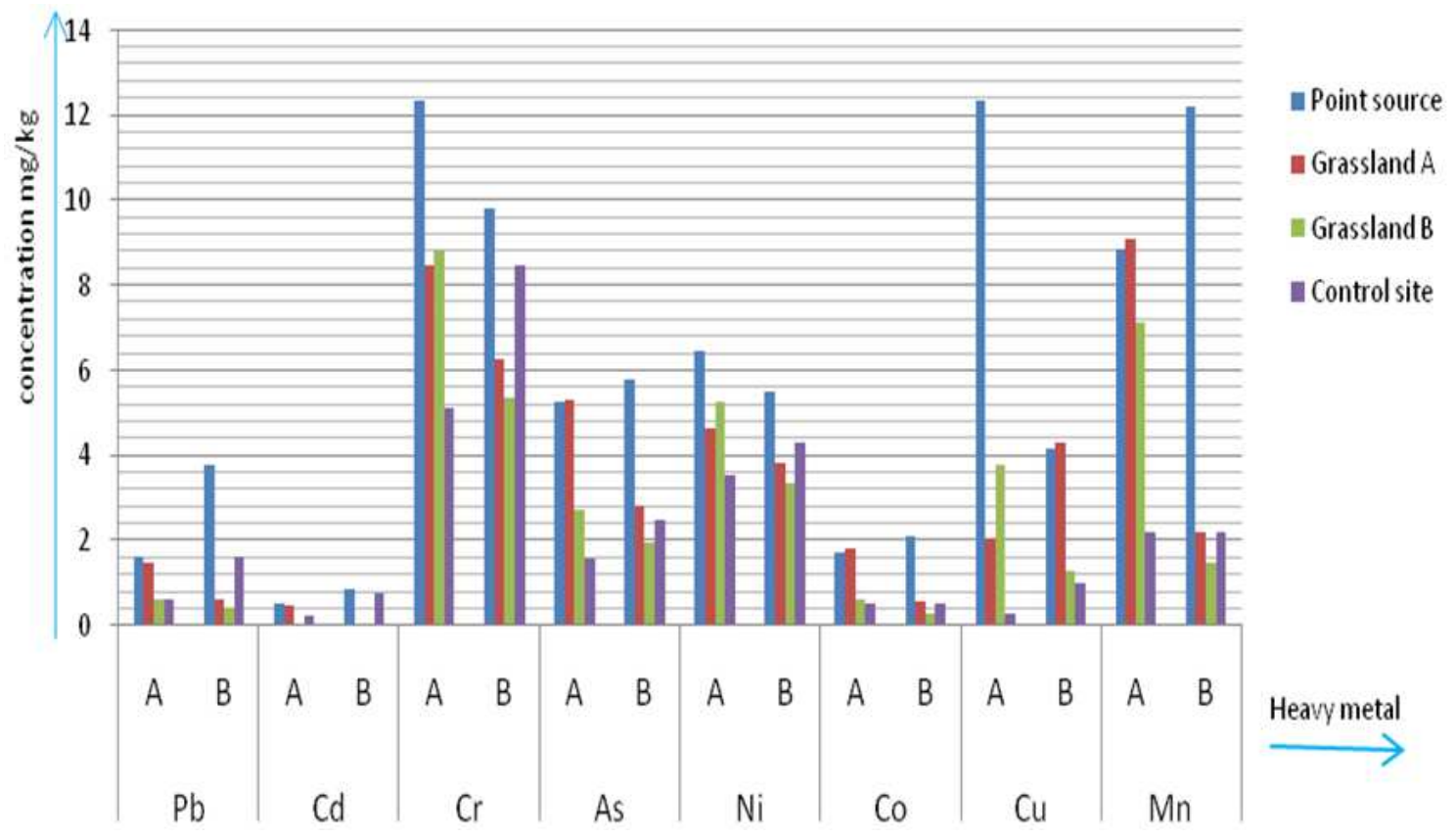

Fig. 1. Mean concentrations of the heavy metals in the soil samples collected at the study area $\left(\mathrm{n}=8,[\mathrm{Mn}]=\mathrm{x} 10^{1}, \mathrm{~A}=0-15 \mathrm{~cm}\right.$ soil depth, $\mathrm{B}=15-30 \mathrm{~cm}$ soil depth)

Table 1. ANOVA between the heavy metals concentrations in the soil samples

\begin{tabular}{lllllll}
\hline Source of variation & SS & df & MS & F & P-value & F crit \\
\hline Between groups & 6544.855 & 7 & 934.9793 & 4.356503 & 0.003054 & 2.422629 \\
Within groups & 5150.806 & 24 & 214.6169 & & & \\
Total & 11695.66 & 31 & & & & \\
\hline
\end{tabular}

Statistical significance $(p<0.05)$ 
As shown in Table 1 above, the result of Analysis of Variance (ANOVA) between the heavy metals concentrations in the soil samples was statistically significant $(\mathrm{p}<0.05)$. This might be due to the varying degree of metal inputs from anthropogenically derived sources across the sampling sites. The point source is the Katima Mulilo municipal solid wastes dumpsite; the grassland is located $1.8 \mathrm{~km}$ away from the point source while the control site is located $17 \mathrm{~km}$ from the point source. However, irrespective of the origin of heavy metals in soils, excessive levels of many metals can result in soil quality degradation as well as posing significant hazards to plants, humans, animals and ecosystem's health (Long et al., 2002). Significant amounts of $\mathrm{Cd}$ and $\mathrm{Pb}$ can be transferred from contaminated soil to plants and grasses, causing accumulation of these potentially toxic metals in grazing ruminants, particularly in cattle (Long et al., 2002; Alonso et al., 2013; Miranda et al., 2005) that feed on such plants/grasses.

Generally, the concentrations of the heavy metals recorded across the sampling sites were lower than their maximum permissible concentrations in soil recommended by WHO (Table 2). However, the presence of the heavy metals in the soils, especially of grassland where humans and livestock graze intensively constitutes health concern due to frequent exposure to the contaminant-bearing dusts emanating from the grassland. Heavy metals may enter the human body through inhalation of dust, direct ingestion of soil and water, dermal contact of contaminated soil and water and consumption of vegetables grown in contaminated fields (Qu et al., 2012). Thus, ingestion, inhalation and absorption constitute the major routes of human and livestock exposure to heavy metals in the study area. Heavy metals toxicity is a clinically significant condition when it does occur (Ferner, 2001) and if unrecognized or inappropriately treated, the toxicity can result in significant illness and reduced quality of life (Amirah et al., 2013). Heavy metal-induced toxicity and carcinogenicity involves many mechanistic aspects, some of which are not clearly elucidated or understood and each metal is known to have unique features and physico-chemical properties that confer its specific toxicological mechanisms of action (Tchounwou et al., 2012). In the biological systems, heavy metals have been reported to affect cellular organelles and components such as cell membrane, mitochondrial, lysosome, endoplasmic reticulum, nuclei and some enzymes involved in metabolism, detoxification and damage repair (Wang and Shi, 2001). Metal ions have also been found to interact with cell components such as DNA and nuclear proteins, causing DNA damage and conformational changes that may lead to cell cycle modulation, carcinogenesis or apoptosis (Wang and Shi, 2001; Chang et al., 1996; Beyersmann and Hartwig, 2008; Kirpichtchikova et al., 2006). Thus, for the protection of humans and animals from unintended exposure to heavy metal contaminants in our environment, it is important to evaluate and document the presence and sources of heavy metals in every environmental component that affects human and animal lives.

\section{Contamination Factors of the Heavy Metals in the Soils}

Figure 2 shows the contamination factor indices of the heavy metals determined in the soil samples. The trend of the results revealed that $\mathrm{As}>\mathrm{Cd}>\mathrm{Cr}=\mathrm{Cu}>\mathrm{Ni}$ $>\mathrm{Mn}>\mathrm{Co}>\mathrm{Pb}$. The higher contamination indices recorded for $\mathrm{As}, \mathrm{Cd}$ and $\mathrm{Cr}$ in the upper soil depth (0-15 $\mathrm{cm})$ suggests that this soil zone could accumulate the metals after prolonged period to potentially toxic levels. This is probable because heavy metals are environmentally persistent due to their non-degradable nature (Singh et al., 2011). Moreover, it has been established that soils are the major sink for heavy metals released into the environment by anthropogenic activities (Wuana and Okieimen, 2011). Unlike organic contaminants which are oxidized to carbon (IV) oxide by microbial action, most metals do not undergo microbial or chemical degradation (Kirpichtchikova et al., 2006) and hence, accumulate in the environment.

Table 2. Standard criteria used for the assessment of the heavy metals pollution

\begin{tabular}{|c|c|c|c|c|c|}
\hline $\begin{array}{l}\text { Heavy } \\
\text { metal }\end{array}$ & $\begin{array}{l}\text { Soil MPC } \\
(\mathrm{mg} / \mathrm{kg})^{\mathrm{a}}\end{array}$ & $\begin{array}{l}\text { Toxic response } \\
\text { factor }^{\mathrm{b}}\end{array}$ & $\mathrm{Cf}$ assessement criteria ${ }^{\mathrm{b}}$ & Er assessement criteria $^{\mathrm{b}}$ & PEri assessement criteria ${ }^{\mathrm{b}}$ \\
\hline $\mathrm{Pb}$ & 100 & 5 & $\mathrm{Cf}<1$, no contamination & Er $<40$, low risk index & PEri $<150$, low risk index \\
\hline $\mathrm{Cd}$ & 3 & 30 & & & \\
\hline $\mathrm{Cr}$ & 100 & 2 & $\begin{array}{l}1 \leq \mathrm{Cf} \leq 3, \text { moderate } \\
\text { contamination }\end{array}$ & $\begin{array}{l}40 \leq \mathrm{Er}<80 \text { moderate } \\
\text { risk index }\end{array}$ & $\begin{array}{l}150 \leq \text { PEri }<300, \\
\text { moderate risk index }\end{array}$ \\
\hline As & 10 & 10 & & & \\
\hline $\mathrm{Ni}$ & 75 & 5 & $3 \leq \mathrm{CF} \leq 6$, considerable & $80 \leq \mathrm{Er}<160$ & $300 \leq$ PEri $<600$ \\
\hline $\mathrm{Cu}$ & 100 & 5 & contamination & considerable risk index & considerable risk index \\
\hline Co & 30 & 5 & $\mathrm{CF}>6$, high contamination & $\begin{array}{l}160 \leq \mathrm{Er}<320, \text { high } \\
\text { risk index }\end{array}$ & PEri $\geq 600$, high risk index \\
\hline
\end{tabular}

$\mathrm{a}=\mathrm{WHO}, \mathrm{b}=$ Hakanson $(1980), \mathrm{Cf}=$ Contamination factor, $\mathrm{Er}=$ Ecological risk factor, $\mathrm{PEri}=$ Potential ecological risk index 


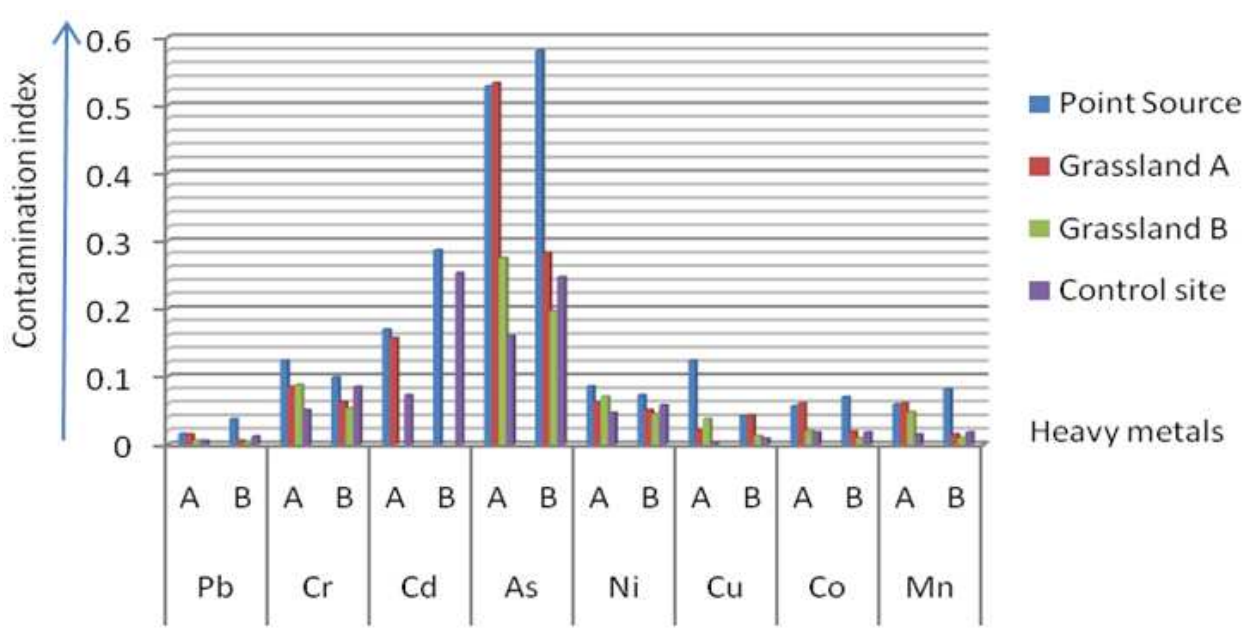

Fig. 2. Contamination factor indices of the heavy metals in soil at the study areas

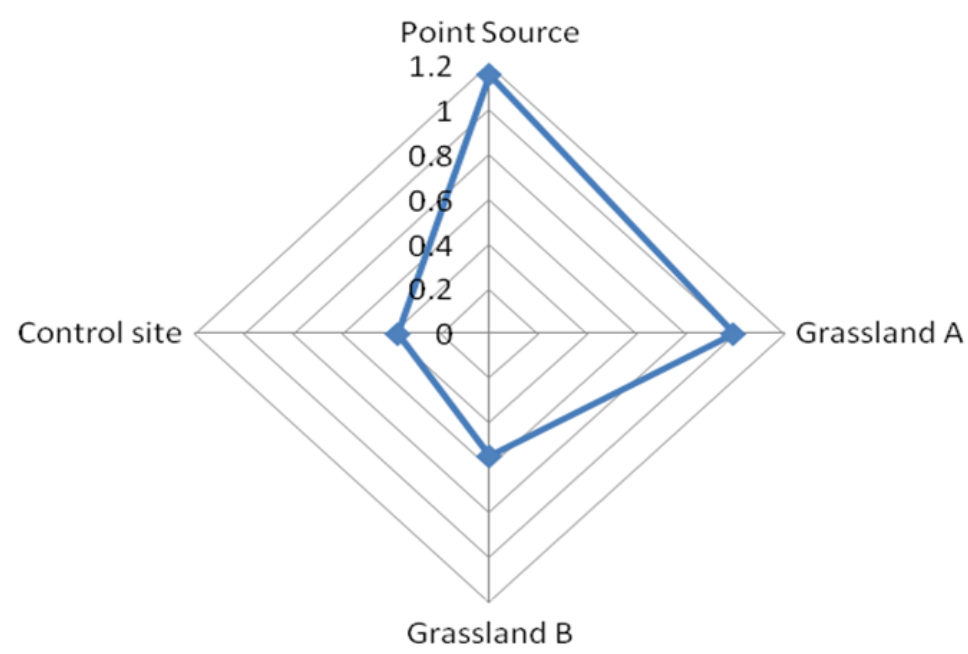

Fig. 3. Radar plot showing the relative degree of heavy metals contamination at the study areas

Figure 3 is a radar plot showing the relative degree of heavy metals contamination of the sampling sites. The trend of the sites contamination revealed that the Point source $>$ Grassland A $>$ Grassland B $>$ Control site. This trend is not suprising because the Point source is the Katima Mulilo municipal solid wastes dumpsite where diverse waste materials are incinerated and left to decay. In a study to assess the in-situ concentrations of some heavy metals in surface soil dusts at the Katima Mulilo urban waste dumpsite, it was reported that solid wastes disposal at the dumpsite is based on open dumping and incineration and these practices have the potential to release toxic metal elements into the environment (Abah et al., 2015). Apart from the natural geochemical process which affects the availability of heavy metals in a given soil, particulates including metals emitted from the dumpsite during incineration are deposited unto the surrounding environment, via atmospheric deposition (Wuana and Okieimen, 2011). Thus, the same or comparative pollution effects may affect any surrounding soil and grassland that are in close proximity to wastes dumpsite.

\section{Ecological Risk Factors of the Heavy Metals}

The results of ecological risk factors (Er) of the heavy metals (Fig. 4) showed that $\mathrm{Cr}$ presents the highest ecological risk factor with an index of 0.824 while $\mathrm{Pb}$ (index $=0.011$ ) present the least. The order of the ecological risk factors revealed that $\mathrm{Cr}>\mathrm{As}>$ $\mathrm{Cd}>\mathrm{Cu}>\mathrm{Ni}>\mathrm{Mn}>\mathrm{Co}>\mathrm{Pb}$. Based on the standard criteria for interpreting ecological risk factors (Table 2 above), the present results generally suggest low ecological risk [Er < 40] (Hakanson, 1980) of the heavy metals across the sampling sites. 


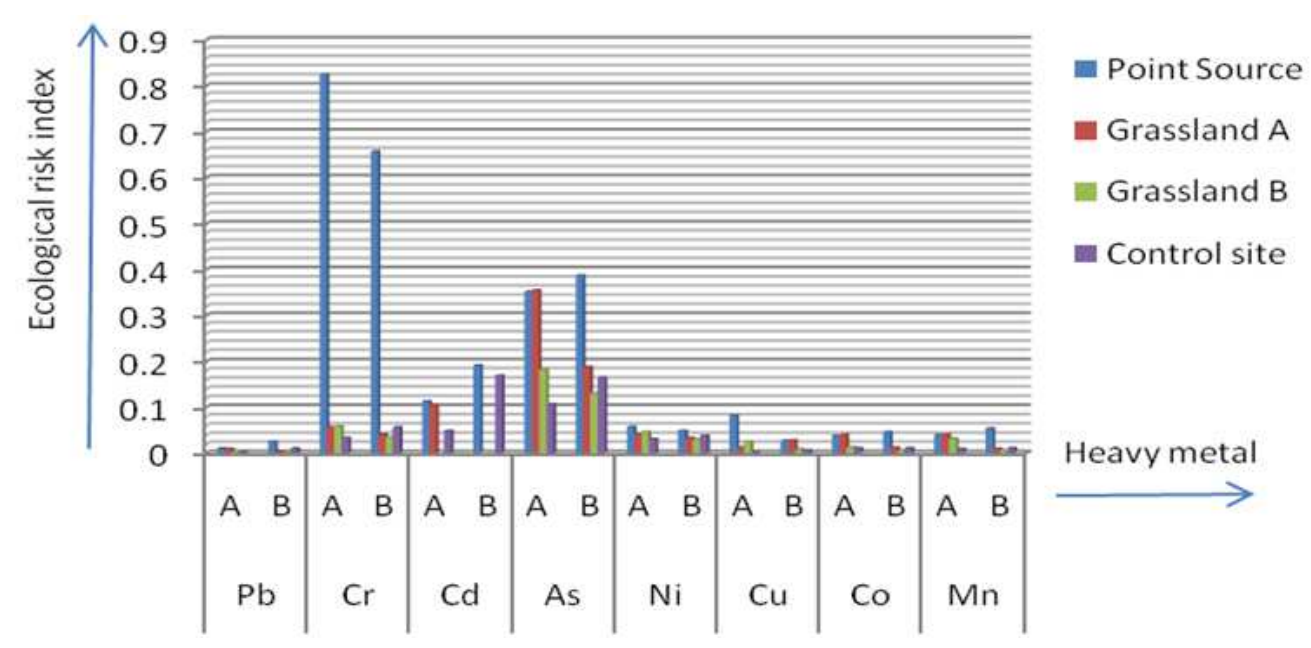

Fig. 4. Ecological risk factors of the heavy metals in soils at the study areas

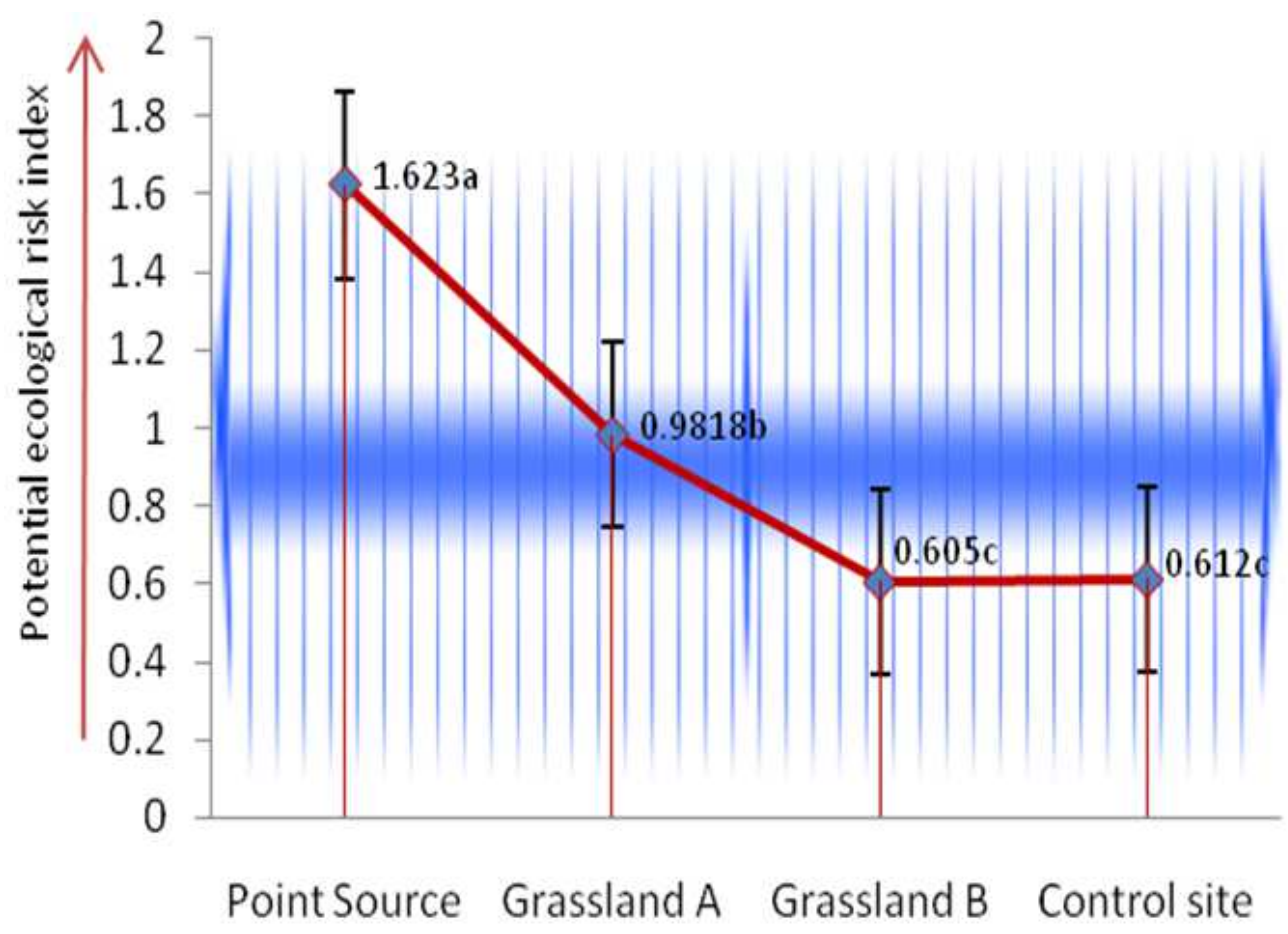

Fig. 5. Potential ecological risk index of the heavy metals across the sampling sites

The Potential Ecological risk index (PEri) of the heavy metals across the sampling sites (Fig. 5) revealed that Point source $>$ Grassland $\mathrm{A}>$ Control site $>$ Grass land B. At the Point source, the risk index was 1.623 while at the grassland A, control site and grassland B, risk indices of $0.981,0.612$ and 0.605 were recorded respectively. These results also differed significantly (t-test paired mean: $\mathrm{p}<0.05)$ between each sampling point and control site except at the grass land B. Based on the criteria for interpreting
PEri of heavy metals in soils (Table 2 above), all the present risk indices represent low level [PEri < 150] (Hakanson, 1980). However, this finding does not preclude concern for accumulation of the heavy metals in the soil since by their nature, metals are non-degradable and hence, environmentally persistent. Moreover, it has been widely acknowledged that the presence of heavy metals in human environment have been associated with different adverse health effects in humans (Tchounwou et al., 2012). 
Table 3. Interelemental correlation analysis between the soil mean heavy metals concentration at the sampling sites

\begin{tabular}{|c|c|c|c|c|c|c|c|c|c|}
\hline & & $\mathrm{Pb}$ & $\mathrm{Cd}$ & $\mathrm{Cr}$ & As & $\mathrm{Ni}$ & $\mathrm{Cu}$ & $\mathrm{Co}$ & $\mathrm{Mn}$ \\
\hline Between point & $\mathrm{Pb}$ & 1.0000 & & & & & & & \\
\hline source and & $\mathrm{Cd}$ & 0.9506 & 1.0000 & & & & & & \\
\hline grassland A & $\mathrm{Cr}$ & 0.9735 & 0.9592 & 1.0000 & & & & & \\
\hline \multirow[t]{5}{*}{ heavy metals } & As & 0.9602 & 0.9477 & 0.9928 & 1.0000 & & & & \\
\hline & $\mathrm{Ni}$ & 0.9649 & 0.9507 & 0.9883 & 0.9864 & 1.0000 & & & \\
\hline & $\mathrm{Cu}$ & 0.9734 & 0.9586 & 0.9968 & 0.9951 & 0.9862 & 1.0000 & & \\
\hline & Co & 0.9582 & 0.9138 & 0.9674 & 0.9620 & 0.9664 & 0.9660 & 1.0000 & \\
\hline & $\mathrm{Mn}$ & 0.9683 & 0.9511 & 0.9956 & 0.9973 & 0.9866 & 0.9984 & 0.9702 & 1.0000 \\
\hline Between point & $\mathrm{Pb}$ & 1.0000 & & & & & & & \\
\hline source and & $\mathrm{Cd}$ & 0.1507 & 1.0000 & & & & & & \\
\hline grassland B & $\mathrm{Cr}$ & 0.9693 & 0.6867 & 1.0000 & & & & & \\
\hline \multirow[t]{5}{*}{ heavy metals } & As & 0.9481 & -0.0990 & 0.9765 & 1.0000 & & & & \\
\hline & $\mathrm{Ni}$ & 0.9282 & 0.3249 & 0.9256 & 0.9124 & 1.0000 & & & \\
\hline & $\mathrm{Cu}$ & 0.9684 & 0.7788 & 0.9810 & 0.9862 & 0.9014 & 1.0000 & & \\
\hline & Co & 0.9369 & -0.3047 & 0.9461 & 0.9405 & 0.8704 & 0.9473 & 1.0000 & \\
\hline & $\mathrm{Mn}$ & 0.9418 & -0.1759 & 0.9683 & 0.9794 & 0.8956 & 0.9788 & 0.9541 & 1.0000 \\
\hline Between point & $\mathrm{Pb}$ & 1.0000 & & & & & & & \\
\hline source and & $\mathrm{Cd}$ & -0.1338 & 1.0000 & & & & & & \\
\hline control site & $\mathrm{Cr}$ & 0.3934 & 0.2464 & 1.0000 & & & & & \\
\hline \multirow[t]{5}{*}{ heavy metals } & As & 0.1028 & -0.1880 & -0.1217 & 1.0000 & & & & \\
\hline & $\mathrm{Ni}$ & 0.4539 & 0.1183 & 0.9579 & -0.0601 & 1.0000 & & & \\
\hline & $\mathrm{Cu}$ & 0.3806 & 0.2283 & 0.9844 & -0.0998 & 0.9581 & 1.0000 & & \\
\hline & $\mathrm{Co}$ & -0.3914 & 0.1030 & -0.2203 & -0.5913 & -0.2140 & -0.2529 & 1.0000 & \\
\hline & Mn & -0.6936 & -0.0607 & -0.5070 & 0.2389 & -0.4507 & -0.4880 & 0.3475 & 1.0000 \\
\hline
\end{tabular}

Inter-Elemental Correlation between the Heavy Metals

The results of the inter-elemental correlation analysis between the heavy metals across the sampling sites were as presented in Table 3. Between the point source (municipal solid wastes dumpsite) and grassland $\mathrm{A}$, the correlation coefficients revealed extremely positive correlation between the heavy metals $(r>0.9)$ with values ranging between 0.9138 to 0.9968 . This suggests that the heavy metals recorded at these sites may have common sources of anthropogenic inputs (Salah et al., 2012). This is very likely since the grassland $\mathrm{A}$ is located just about $1.8 \mathrm{~km}$ away from the point source. Within this proximity, metal particulates emitted into the atmosphere during wastes incineration at the point source could easily be deposited unto the grassland via trans-boundary transfer effect. Between the point source and grassland $\mathrm{B}$, the correlation coefficients of the metals revealed some weak positive correlation $(\mathrm{r}$ $=0.1$ to 0.5$)$, some weak negative correlation $(\mathrm{r}=-0.1$ to -0.5), while majority had extremely positive correlation $(\mathrm{r}>0.9)$. Between the point source and control site, most of the correlation coefficients revealed weak negative and weak positive correlations with values varying between -0.5070 to -0.1217 and 0.1028 to 0.4539 . Extremely weak negative correlation was recorded for $\mathrm{Mn}$ and $\mathrm{Cd}(\mathrm{r}=-0.0607), \mathrm{Ni}$ and $\mathrm{As}(\mathrm{r}$ $=-0.0601)$ as well as $\mathrm{Cu}$ and $\mathrm{As}(\mathrm{r}=-0.0998)$. These weak correlations suggest that the heavy metals recorded at the point source and control site may originate from different sources of anthropogenic inputs (Salah et al., 2015). Considering the location of the control site (17 $\mathrm{km}$ ) from the point source, it is likely that transboundary transfer and deposition of metal particulates emitted from the point source may be greatly affected by wind dispersion. Thus, most of the metal particulates may be deposited before getting to the control site or are even blown away by wind to different locations.

\section{Conclusion}

The results of this study showed varying concentrations of lead $(\mathrm{Pb})$, chromium $(\mathrm{Cr})$, Cadmium (Cd), arsenic (As), nickel (Ni), cobalt (Co), copper $(\mathrm{Cu})$ and manganese $(\mathrm{Mn})$ in the soil samples collected from the Point source, Grasslands and Control site respectively. Across these sampling areas, $\mathrm{Mn}$ recorded the highest mean level while $\mathrm{Cd}$ recorded the least. The analysis of variance (ANOVA) between the heavy metals concentrations in the soil samples was statistically significant $(p<0.05)$. This was attributed to the varying degree of metal inputs from anthropogenically derived sources across the sampling sites. High contamination indices were recorded for As, $\mathrm{Cd}$ and $\mathrm{Cr}$ in the upper soil depth (0$15 \mathrm{c} \mathrm{m}$ ) and these suggest that this soil zone could accumulate the metals after prolonged period to potentially toxic levels. The trend of the sites contamination revealed that the Point source > Grassland A > Grassland B > Control site but the 
current ecological risks indices revealed low levels. Generally, the mean concentrations of the heavy metals recorded across the sampling sites were lower than their corresponding maximum permissible limits recommended by WHO for the protection of human and ecosystem's health. However, the presence of the heavy metals in the soils, especially of the grassland where humans and livestock graze intensively constitutes health concern due to: (1). persistence and non-degradability of heavy metals in the environment with high potential for accumulating to potentially toxic level. (2). frequency of unintended exposure of humans and livestock (a component of human foods) to heavy metals which could lead to bio-accumulation into body tissues with attendant adverse health effects. Therefore, we recommend periodic monitoring of the heavy metals in the grassland and advice precautionary measures to limit excessive human exposures to the metal contents.

\section{Acknowledgement}

The authors greatly acknowledged the financial support provided by the University of Namibia, Katima Mulilo Campus to undertake this study. We are also grateful to the Katima Mulilo Town Council for the approval granted us to carry out the study on the grassland. Finally, we are thankful to the technologists of Analytical Services Laboratory, Windhoek Namibia for the conducive analytical conditions provided for the laboratory preparations and analysis of the samples. God bless.

\section{Author's Contributions}

J. Abah: Designed the study and participated in all the field works, laboratory analysis, literature search, data analysis and writing the manuscript.

P. Mashebe: Participated in all the field works, laboratory analysis, data analysis, checking and editing the manuscript.

S.A. Onjefu: Participated in all the laboratory analysis, literature search, data analysis, checking and editing the manuscript.

\section{Publication Ethics}

The authors hereby affirm that this article is an original work of the authors and it is not under consideration for publication either in whole or part by any other journal. All literature sources were duly referenced. All the authors read and approved the publication of the article.

\section{Conflict of Interest}

The authors hereby declare that there is no conflict of interest regarding the publication of this article.

\section{References}

Abah, J., P. Mashebe and S.A. Onjefu, 2014. Survey of the levels of some heavy metals in roadside dusts along Katima Mulilo urban road construction, Namibia. Am. J. Environ. Protect., 3: 19-27. DOI: $10.11648 /$ j.ajep.20140301.13

Abah, J., P. Mashebe, S.A. Onjefu and S.P. Malu, 2015. Assessment of the In-situ concentrations of some heavy metals in surface soil dusts at the Katima Mulilo urban waste dumpsite, Namibia. Int. J. Adv. Sci. Tech. Res., 4: 88-100.

ATSDR, 2003. Toxicological profile for arsenic. U.S. Department of Health and Human Services, Public Health and Humans Services, Center for Disease Control, Atlanta.

Alonso, C.M.L., T. Sánchez, A.E. Vereda, T.A. García and P.J.M. Cano, 2013. Bioavailability of heavy metals in water and sediments from a typical Mediterranean Bay (Málaga Bay, Region of Andalucía, Southern Spain). Mar. Pollut. Bull.. 76: 427-434. DOI: 10.1016/j.marpolbul.2013.08.031

Amirah, M.N., A.S. Afiza, W.I.W. Faizal, M.H. Nurliyana and S. Laili, 2013. Human health risk assessment of metal contamination through consumption of fish. J. Environ. Pollut. Human Health, 1: 1-5. DOI: 10.12691/jephh-1-1-1

Beyersmann, D. and A. Hartwig, 2008. Carcinogenic metal compounds: Recent insight into molecular and cellular mechanisms. Arch Toxicol., 82: 493-512. DOI: $10.1007 / \mathrm{s} 00204-008-0313-y$

Bretzel, F.C. and M. Calderisi, 2011. Contribution of a municipal solid waste incinerator to the trace metals in the surrounding soil. Environ. Monit. Assess, 182: 523-533. DOI: 10.1007/s10661-011-1894-0

Chang, L.W., L. Magos and T. Suzuki, 1996. Toxicology of Metals. 1st Edn., CRC Press, Boca Raton. FL, USA, ISBN-10: 1566708036, pp: 1198.

D'Amore, J.J., S.R. Al-Abed, K.G. Scheckel and J.A. Ryan, 2008. Methods for speciation of metals in soils: A review. J. Environ. Quality, 34: 1707-1745. DOI: $10.2134 /$ jeq2004.0014

EPA, 1996. EPA Method 3050B for acid digestion of sediments, sludge and soils.

Ferner, D.J., 2001. Toxicity, heavy metals. eMed. J., 2: $1-1$.

Hakanson, L., 1980. An ecological risk index for aquatic pollution control: A sedimentological approach. Water Res., 14: 975-1001. DOI: $10.1016 / 0043-1354(80) 90143-8$

Ideriah, T.J.K., F.O Harry, H.O. Stanley and J.K. Igbara, 2010. Heavy metal contamination of soils and vegetation around solid waste dumps in Port Harcourt, Nigeria. J. Applied Sci. Environ. Manage., 14: 101-109. DOI: 10.4314/jasem.v14i1.56511 
IOSHIC, 1999. Metals. In: Basics of Chemical Safety, International Labour Organization, Geneva.

Iwegbue, C.M.A., G.E. Nwajei, J.E. Ogala and C.L. Overah, 2010. Determination of trace metal concentrations in soil profiles of municipal waste dumps in Nigeria. Environ. Geochem. Health, 32: 415-430. DOI: 10.1007/s10653-010-9285-y

Kirpichtchikova, T.A., A. Manceau, L. Spadini, F. Panfili and M.A. Marcus et al., 2006. Speciation and solubility of heavy metals in contaminated soil using X-ray microfluorescence, EXAFS spectroscopy, chemical extraction and thermodynamic modeling. Geoch. Cosmochimica Acta, 70: 2163-2190.

DOI: $10.1016 /$ j.gca.2006.02.006

Ling, W., Q. Shen, Y. Gao, X. Gu and Z. Yang, 2007. Use of bentonite to control the release of copper from contaminated soils. Austral. J. Soil Res., 45: 618-623. DOI: $10.1071 /$ SR07079

Long, X.X., X.E. Yang and W.Z. Ni, 2002. Current status and prospective on phytoremediation of heavy metal polluted soils. J. Applied Ecol., 13: 757-62.

Mandal, A. and D. Sengupta, 2006. An assessment of soil contamination due to heavy metals around a coal-fired thermal power plant in India. Environ. Geol., 51: 409-420. DOI: 10.1007/s00254-006-0336-8

McLaughlin, M.J., B.A. Zarcinas, D.P. Stevens and N. Cook, 2000a. Soil testing for heavy metals. Commun. Soil Sci. Plant Anal., 31: 1661-1700. DOI: 10.1080/00103620009370531

McLaughlin, M.J., R.E. Hamon, R.G. McLaren, T.W. Speir and S.L. Rogers, 2000b. Review: A bioavailability-based rationale for controlling metal and metalloid contamination of agricultural land in Australia and New Zealand. Australian J. Soil Res., 38: 1037-1086. DOI: 10.1071/SR99128

Miranda, M., M.L. Alonso, C. Castillo, J. Hernández and J.L. Benedito, 2005. Effects of moderate pollution on toxic and trace metal levels in calves from a polluted area of northern Spain. Environ. Int., 31: 543-548. DOI: 10.1016/j.envint.2004.09.025

OSHA, 1991. Substance data sheet for Occupational exposure to Lead. Occupational Safety and Health Administration.

Qu, C.S., Z.W. Ma, J. Yang, Y. Liu and J. Bi et al., 2012. Human exposure pathways of heavy metals in a lead-zinc mining area, Jiangsu Province, China. PLoS One, 7: e46793-e46793.

DOI: 10.1371 /journal.pone.0046793

Qui, H., 2010. Studies on the potential ecological risk and homology correlation of heavy metal in the surface soil. JAS, 2: 194-201.
Rahman, S.H., D. Khanam, T.M. Adyel, M.S. Islam and M.A. Ahsan et al., 2012. Assessment of heavy metal contamination of agricultural soil around Dhaka Export Processing Zone (DEPZ), Bangladesh: implication of seasonal variation and indices. Applied Sci., 2: 584-601. DOI: 10.3390/app2030584

Rashad, M. and E.A. Shalaby, 2007. Dispersion and deposition of heavy metals around two Municipal Solid Waste (MSW) dumpsites, Alexandria, Egypt. Am. Eurasian J. Agric. Environ. Sci., 2: 204-212.

Rizo, O.D., M.H. Merlo, F.E. Castillo and J.A.O. Lopez, 2012. Assessment of metal pollution in soils from a former Havana (Cuba) solid waste open dump. Environ. Contam. Toxicol., 88: 182-186. DOI: $10.1007 / \mathrm{s} 00128-011-0505-7$

Salah, E.A., T.M. Ahmed and M.N. Shemma, 2015. Chemometric evaluation of the heavy metals in urban soil of Fallujah City, Iraq. J. Environ. Protect., 6: 1279-1292. DOI: $10.4236 /$ jep. 2015.611112

Salah, E.A.M., Z.A.Tahseen and A.S. Ahmed, 2012. Assessment of heavy metals pollution in the sediments of Euphrates River, Iraq. J. Water Resource Protect., 4: 1009-1023. DOI: 10.4236/jwarp.2012.412117

Singh, R., G. Neetu, M. Anurag and G. Rajiv, 2011. Heavy metals and living systems: An overview. Ind. J. Pharmacol., 43: 246-253. DOI: $10.4103 / 0253-7613.81505$

Sposito, G. and A.L. Page, 1984. Cycling of Metal Ions in the Soil Environment. In: Metal Ions in Biological Systems, Sigel, H. (Ed.), Marcel Dekker, Inc., New York, USA, pp: 287-332.

Tchounwou, P.B., C.G. Yedjou, A.K. Patlolla and D.J. Sutton, 2012. Heavy metal toxicity and the environment. EXS, 101: 133-164. DOI: 10.1007/978-3-7643-8340-4_6

Waheed, S., N. Siddique, Q. Hamid and M.M. Chaudhry, 2010. Assessing soil pollution from a municipal waste dump in Islamabad, Pakistan: A study by INAA and AAS. J. Radioanal. Nucl. Chem., 285: 723-732. DOI: 10.1007/s10967-010-0623-4

Wang, S. and X. Shi, 2001. Molecular mechanisms of metal toxicity and carcinogenesis. Mol. Cell. Biochem., 222: 3-9. DOI: $10.1023 / \mathrm{A}: 1017918013293$

Wuana, R.A. and F.E. Okieimen, 2011. Heavy metals in contaminated soils: A review of sources, chemistry, risks and best available strategies for remediation. ISRN Ecol., 2011: 402647-402647. DOI: $10.5402 / 2011 / 402647$ 